\title{
Implementasi Smart Glove untuk Monitoring Jari Tangan dan Detak Jantung Pasien Pasca Stroke
}

\author{
Fajar Setiawan ${ }^{1}$, Son Ali Akbar ${ }^{2}$ \\ [Submission: 04-06-2021, Accepted: 13-08-2021]
}

\begin{abstract}
Stroke is a condition that occurs when blood supply to the brain clogged. This disease is one of deadly. One effect of paralyzed arm is in motion on the fingers of the hand system. This study designed a smart glove that can detect the gesture fingers. Smart design glove is used five fruit flex sensors placed on the fingers, System do reading data from sensors flex will be processed by micro kontroller arduinonano, Next data will be sent to the visual built use a visual basic appear in real time. Smart glove is also equipped with sensor technology grove finger clip heart rate used to detect the condition of cardio or heart rate in patients after a stroke with a base of IOT(Internet Of Things). System and do it by micro kontroller ESP-8266 as the delivery of data to software blynk. The results of tests carried out shows that obtained the results of a value of resemblance above $90 \%$ and the testing censorship grove finger clip heart rate obtained the accuracy of 99. $05 \%$.
\end{abstract}

Intisari - Penyakit stroke merupakan keadaan pada saat dikala suplai darah ke otak tersumbat. Penyakit ini merupakan salah satu penyebab kematian. Salah satu akibat kelumpuhan pada lengan yakni kelainan pada sistem gerak jari tangan. Penelitian ini dirancang sebuah smart glove yang dapat mendeteksi gestur jari-jari tangan. Perancangan smart glove ini digunakan lima buah flex sensor yang diletakkan pada jari tangan, sistem melakukan pembacaan data dari sensor flex akan diproses oleh mikrokontroller arduino nano, selanjutnya data akan di kirim ke aplikasi yang dibangun menggunakan visual basic tertampil grafik secara real time. Smart glove ini juga dilengkapi dengan teknologi sensor grove finger clip heart rate digunakan untuk mendeteksi kondisi kardio atau denyut jantung pada pasien pasca stroke dengan basis IoT (Internet of Things). Sistem melakukan pembacaan oleh mikrokontroller dan ESP-8266 sebagai pengiriman data ke software blynk. Hasil pengujian yang dilakukan menunjukkan bahwa diperoleh data hasil $85 \%$ keberhasilan atau kemiripan data gerak jari-jari tangan dengan nilai kemiripan diatas $90 \%$ dan hasil pengujian sensor grove finger clip heart rate didapatkan tingkat akurasi sebesar $99.05 \%$.

Kata Kunci-Stroke, Smart Glove, Sensor Flex, Sensor Grove Finger Clip Heart Rate, Grafik Real Time, Visual Basic, Blynk.

\section{PENDAHULUAN}

\footnotetext{
${ }^{1}$ Mahasiswa,Program Studi Trknik Elektro Fakultas Teknologi Industri Universitas Ahmad Dahlan, Jalan Ring Road Selatan, Tamanan, Banguntapan 55166 INDONESIA (tlp: 0274-563515; fax: 5646604; e-mail: fajar1700022002@webmail.uad.ac.id)

2, Dosen Program Studi Teknik Elektro Fakultas Teknologi Industri Universitas Ahmad Dahlan, Jalan Ring Road Selatan, Tamanan, Banguntapan 55166 INDONESIA ; (tlp: 0274-563515; fax: 5646604 e-mail: sonali@ee.uad.ac.id)
}

Fajar Setiawan: Implementasi Smart Glove untuk ...
Stroke merupakan suatu kondisi ketika darah ke otak terputus akibat penyumbatan ataupun pecahnya pembuluh darah yang menyebabkan kematian sel di beberapa area otak [1]. Stroke adalah penyebab utama kecacatan jangka panjang di seluruh dunia [2]. Stroke terdiri dari dua jenis, yaitu stroke hemorhagic dan ischemic. Jumlah penderita penyakit stroke ischemic lebih besar, yaitu sebesar $87 \%$ dari seluruh penderita stroke [3]. Faktor ini dibagi menjadi beberapa faktor yang tidak dapat berubah seperti genetika, jenis kelamin, serta umur. Sedangkan faktor yang dapat berubah adalah hipertensi, serangan jantung dan gaya hidup seperti perilaku merokok, konsumsi alkohol, dan diabetes melitus. [4]. Salah satu dampak stroke akan mengalami kelumpuhan pada lengan seperti kelainan sistem gerak pada jari-jari yang sangat mempengaruhi kualitas hidupnya [5]. Bersumber pada informasi dari Riset Kesehatan Dasar (Riskesdas) yang dilakukan pada tahun 2018 menyatakan bahwa penyakit stroke semakin meningkat dan darurat karena jumlah penderita stroke di Indonesia tertinggi di Asia. Hasil prevalensi stroke di Indonesia ditemui sebesar 10,9\% per 1000 penduduk jumlah ini bertambah pada tahun sebelumnya sebesar 7,0\% per 1000 penduduk Indonesia. Angka penderita stroke kasus tertinggi berada pada umur $\geq 45$ tahun.

Hal-hal yang harus diperhatikan saat melakukan terapi fisik misalnya: terapi fisik menitikberatkan pada latihan strength, balance, stability, terapi harus diawali dengan melakukan pemanasan supaya otot dan persendian tidak kaku, harus disesuaikan dengan kemampuan pasien, dan dilakukan menggunakan alat bantu. Terapi fisik bisa dimulai secara bertahap saat penderita stroke masih terbaring di tempat tidur, namun kondisi pasien sudah dinyatakan stabil oleh dokter. Rehabilitasi pasien stroke dapat dilakukan dengan melakukan gerakan-gerakan seperti menunjukkan nomor isyarat $1,3,5,7$, 9, 10 dan keadaan jari menggenggam. Latihan ini dapat memulihkan mobilitas jari yang sakit.

Pada penelitian ini dikembangkan alat terapi jari dengan penelitian ini mengacu pada penelitian sebelumnya yang dilakukan oleh Mila Rahmadiva tentang merancang bangun hand tracking glove sebagai antarmuka game rehabilitasi dengan menggunakan 10 sensor flex pada bagian jarinya. Sensor flex akan membaca sudut pergerakan jari-jari. Hasil pembacaan sensor flex akan dikirim secara serial dari arduino ke PC [6]. Penelitian berupa pengembangan alat bantu komunikasi penderita pasca stroke menggunakan sensor flex dan accelerometer oleh Agung W. Setiawan [7]. Penelitian berupa pemantauan sistem detak jantung dan lokasi pasien dikembangkan menggunakan arduino yang dihubungkan dengan sensor detak jantung, modem GSM, dan modul GPS. Sensor detak jantung pasien kemudian diproses oleh arduino

p-ISSN:1693 - 2951; e-ISSN: 2503-2372 
sehingga dapat ditampilkan dalam bentuk BpM (Beat per Menit). Selain itu juga koordinat posisi diperoleh dari komponen GPS dan ditampilkan url google maps [8]. Dan penelitian berupa aplikasi mhealth dalam deteksi, monitoring dan perubahan gaya hidup pasien penyakit jantung yang bertujuan untuk mencegah dan monitoring pasien penyakit jantung dengan menggunakan aplikasi mhealth oleh Vema [9].

Pada penelitian ini dikembangkan alat terapi jari dengan metode terapi berupa gerak aktif yang dipasang 5 buah sensor flex untuk mendeteksi gestur setiap gerakan jari-jari tangan pada penderita stroke. Data yang diambil selanjutnya akan diproses oleh mikrokontroler arduino nano selanjutnya data akan dikirim ke aplikasi yang dirancang menggunakan microsoft visual basic 2010 untuk dirubah menjadi grafik real time dengan disertai nilai presentase kemiripan. Smart glove dilengkapi teknologi sensor mendeteksi denyut jantung pasien dipasang pada ujung jari, kemudian diproses oleh arduino nano sehingga bisa direpresentasikan dalam bentuk BpM (Beat per Menit) data akan dikirim ke aplikasi blynk pada smartphone. Teknologi ini diharapkan dapat mempermudah terapis dan pasien sehingga meningkatkan efektivitas terapi fisik bagi pemulihan pasca stroke.

\section{METODE PENELITIAN}

Penelitian ini menggunakan perangkat keras mikrokontroler berupa arduino nano yang bertugas sebagai pengendali dan pembaca data adc (analog digital converter) output dari sensor flex serta melakukan pengolahan data. Rancangan rangkaian-rangkaian sensor serta baterai dan $D C$ step up converter untuk menyuplai tegangan pada seluruh perangkat keras yang digunakan dalam penelitian ini. Blok diagram penelitian dapat ditunjukan pada Gambar 1 .

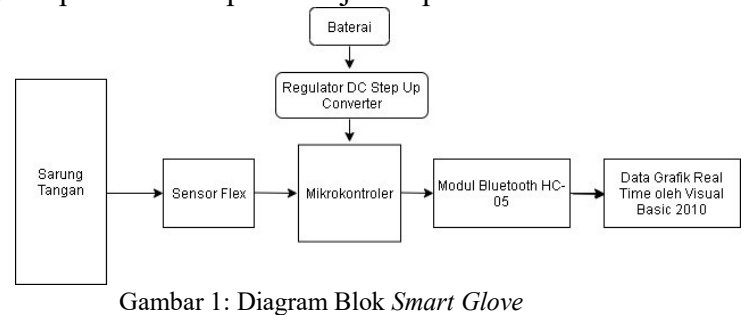

Pada Gambar 1 menjelaskan tentang bagian suplai tegangan diperoleh dari regulator DC 5 volt yang memiliki fungsi Sebagai penambah tegangan dari baterai berkapasitas 3.7 volt. Proses selanjutnya input sensor flex sebanyak 5 buah dipasang pada masing-masing jari. Dalam prosesnya, mikrokontroler arduino nano dapat melakukan berbagai pembacaan data dari sensor dan mentransfer data ke aplikasi menggunakan modul bluetooth HC-05.

Hasil pembacaan yang telah diolah akan di tampilkan ke aplikasi microsoft visual basic 2010. Diagram alir dapat ditunjukan pada Gambar 2 berikut ini.

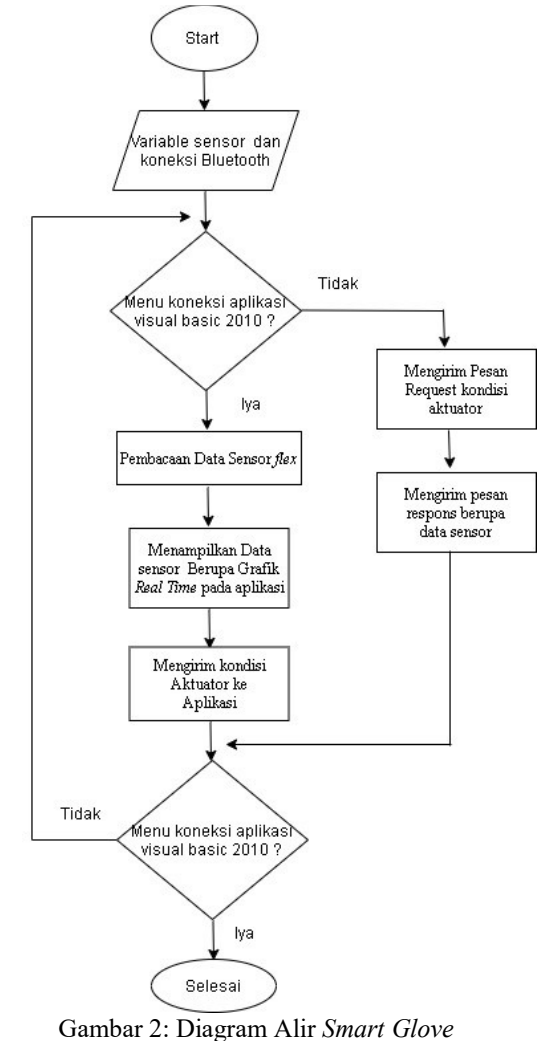

Pada Gambar 2 diagram alir dapat menyatakan bahwa di bagian input berupa sensor flex. Pada saat sistem memulai, sistem akan menjalankan pembacaan data dari sensor flex. Setelah pembacaan data berhasil akan diolah melalui arduino nano, selanjutnya proses pengiriman data secara serial melalui koneksi wireless menggunakan modul bluetooth $\mathrm{HC}-05$. Proses selanjutnya data yang terkirim akan dilakukan pembacaan data dengan aplikasi yang telah dirancang menggunakan microsoft visual basic 2010. kemudian visual basic akan memproses pembacaan dan pengolahan data dari sensor flex diproses data berupa adc (analog digital converter) melalui arduino nano, data tersebut tertampil dalam bentuk grafik real time yang berubah sesuai dengan gerakan jari. Dalam proses membaca data dan menampilkan data ke dalam grafik, proses tersebut diulang terus menerus hingga sistem dimatikan. Diagram blok deteksi jantung yang dirancang dalam penelitian ini dapat ditunjukan pada Gambar 3.
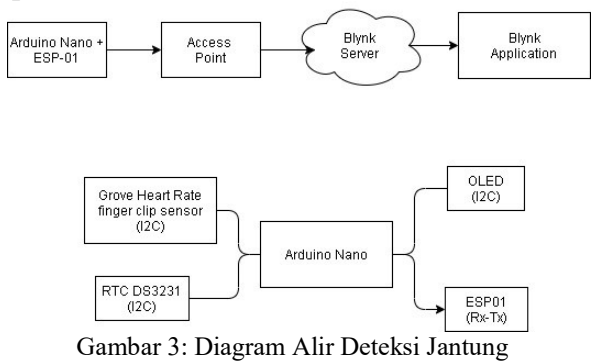

Pada Gambar 3 menjelaskan tentang digram blok proses monitoring detak jantung. Pembacaan sensor berupa nilai analog dan diubah menjadi nilai digital melalui ADC (Analog Digital Converter). Proses pertama dideteksi detak jantung oleh pembacaan sensor grove finger clip heart rate akan di proses 
DOI: https://doi.org/10.24843/MITE.2021.v20i02.P12

oleh mikrokontroler arduino nano. RTC akan membaca waktu yang diolah mikrokontroler arduino nano. Dari hasil pembacaan sensor grove finger clip heart rate dan RTC DS3132 lalu dikirim serial pada board Esp 8266-01 yang sudah tersambung dengan tegangan. Hasil pembacaan yang telah diolah akan ditampilkan ke oled dan dikirimkan pada software blynk. Diagram alir dapat dilihat pada Gambar 4.

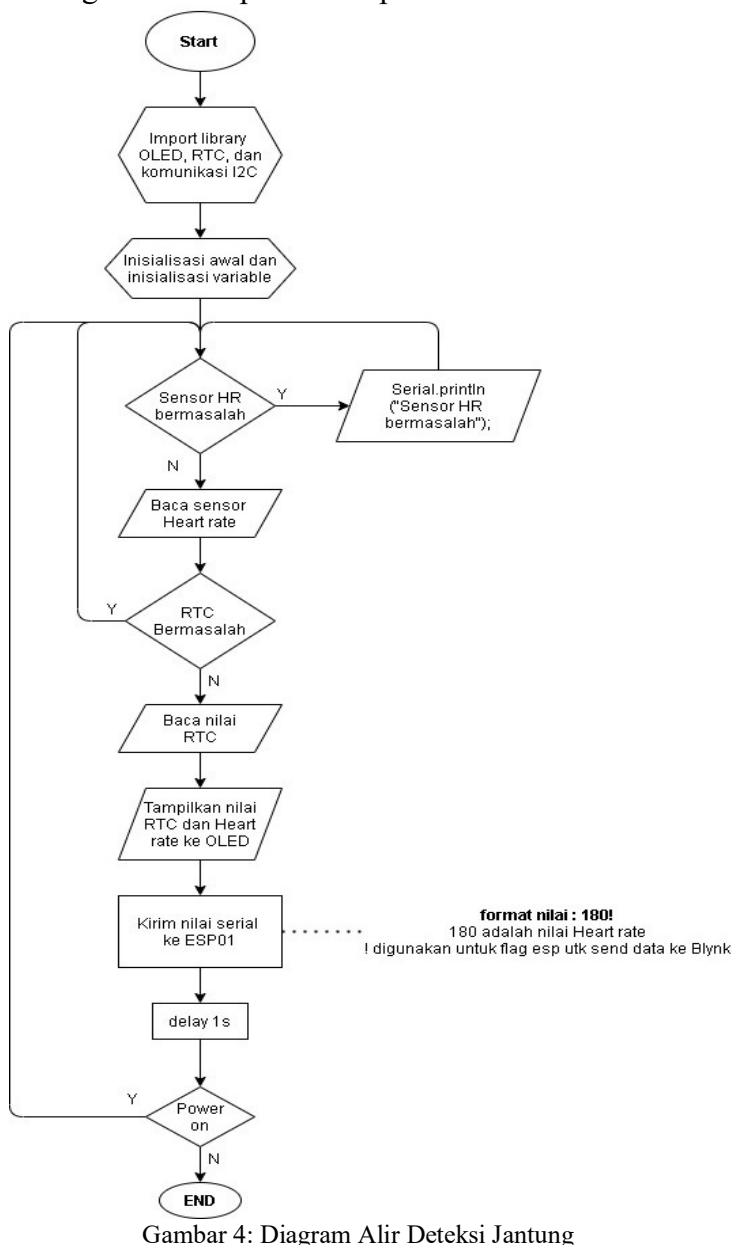

Pada Gambar 4 diagram alir menjelaskan tentang proses awal mode inisialisasi, selanjutnya arduino nano melakukan pembacaan dan pemrosesan inisialisasi, ketika sistem mengalami kesalahan pengaturan maka tombol reset akan berfungsi sebagai reset nilai menjadi nol. Pada pemrosesannya, arduino nano melakukan pembacaan dari sensor HR dan akan mengirimkan nilai pembacaan HR ke Esp 8266-01. Selanjutnya Esp 8266-01 akan mengirimkan komunikasi serial pada aplikasi blynk tertampil tanggal, waktu, nilai output rtc, jika tidak sesuai maka melakukan update pada program, arduino nano memperbarui data dan menjalankan kembali yang akan tertampil data pada layar oled dan aplikasi blynk.

\section{A. Internet of Things (IoT)}

Kemajuan teknologi dapat diterapkan pada kegiatan pengawasan kesehatan, salah satunya yaitu teknologi Internet of Things (IoT) [10]. Smart health merupakan salah satu upaya teknologi Internet of Thing (IoT) dapat diintegrasikan ke dalam layanan kesehatan seperti, pemantauan kesehatan, Fajar Setiawan: Implementasi Smart Glove Untuk... pendeteksian kesehatan, consultation kesehatan, dan management kesehatan [11]. Penerapan IoT adalah dimana objek dapat berkomunikasi dengan objek lain atau sensor tertanam yang terhubung ke jaringan [12].

\section{B. Arduino Nano}

Arduino nano adalah mikro komputer yang didukung mikrokontroler Atmega328 V3 yang mempunyai chip IC associate (integrated circuit) yang terdiri dari prosesor, memori, dan antarmuka yang dapat diprogram. Arduino nano memiliki empat belas pin digital I / O, memiliki tegangan operasi 5 volt [13]. Arduino nano dapat mempermudah dalam proses pengendalian dan pengontrolan terhadap sensor yang digunakan pada proses pemrograman [14].

C. NodeMcu ESP8266-01

Modul ini memiliki kesamaan seperti Arduino, namun hanya mempunyai 2 pin sebagai I / O. Modul ini terintegrasi dengan protokol TCP / IP sehingga mikrokontroler (ESP 826601) bisa tersambung ke jaringan WiFi. Modul ESP 8266-01 bisa diisi dengan perintah ataupun program dengan melakukan flash terlebih dahulu [15].

\section{Bluethooth HC-05}

Bluetooth merupakan protokol komunikasi nirkabel dapat bekerja di frekuensi radio 2,4 GHz untuk melakukan pertukaran data di perangkat keras seperti personal digital assistant, laptop, smartphone, dan lain-lain. Modul ini dapat digunakan sebagai mode budak atau master [16]. Untuk membantu perangkat bluetooth, diperlukan perintah AT dimana perintah AT akan bertanggung jawab pada perangkat bluetooth jika modul bluetooth tidak dapat terhubung ke perangkat lain [17].

E. Sensor Flex

Sensor flex juga dikenal sebagai sensor fleksibilitas, digunakan untuk membaca lekukan dari sensor. Hasil dari sensor berupa tegangan analog yang dapat langsung diproses ke mikrokontroler melalui fasilitas ADC [18]. Sensor fleksibel dapat diterapkan pada beberapa perangkat, biasanya digunakan untuk kontrol robot, sebagai pembaca sinyal tangan digital, serta pembaca gerak jari [19].

\section{F. Grove Finger Clip Heart Rate}

Modul sensor memakai PAH8001EI- 2G, satu buah "CMOS- process optical" yang mempunyai performa teratas serta mengkonsumsi daya yang rendah, dengan led hijau terintegrasi dan DSP yang berperan selaku sensor detak jantung. led hijau dipancarkan ke aliran darah, setelah itu memantul kembali ke optik di mana pantulan ini kemudian tiba untuk menghasilkan informasi detak jantung per detik yang akurat. [20].

\section{G. Microsoft Visual Basic 2010}

Microsoft Visual Basic (VB) merupakan perangkat lunak dengan bahasa pemrograman Integrated Development Environment (IDE) tampilan visual membuat program berupa aplikasi berbasis operating system microsoft windows menggunakan versi pemrograman (COM) [21]. Visual basic adalah turunan dari bahasa pemrograman basic dan menawarkan perkembangan pesat aplikasi komputer grafis. Memilki beberapa bahasa skrip yaitu, Visual Basic for Applications (VBA) dan Visual Basic Scripting Edition (VBScript), serupa dengan Visual Basic, akan tetapi mempunyai cara kerja yang berbeda [22].

p-ISSN:1693 - 2951; e-ISSN: 2503-2372 


\section{H. Blynk}

Blynk adalah platform yang digunakan untuk membangun antarmuka untuk mengontrol dan memantau proyek perangkat keras dari perangkat iOS dan Android. Blynk adalah layanan Internet of Things (IOT) yang dibangun untuk membuat kontrol remot dan pembacaan data sensor dari perangkat arduino atau Esp 8266-01 [24]. Blynk adalah digital dashboard yang dapat digunakan untuk membangun antarmuka grafis untuk alat yang telah dibuat hanya dengan menyeret dan menjauhkan widget [25].

\section{PENGUJIAN SISTEM}

\section{A. Hardware}

Pengujian Flex Sensor

Sensor flex digunakan untuk mendeteksi gestur jari tangan dengan fleksibilitas dan ketahanannya. Untuk pembacaan suatu gestur jari digunakan aturan pembagi tegangan. Pembagi tegangan dasar digunakan untuk koneksi sirkuit antara mikrokontroler dan sensor fleksibel. Untuk mendapatkan nilai ADC 10-bit, gunakan rumus berikut :

$$
\text { Data } \mathrm{ADC}=\frac{\text { Vin } \times 1024}{\text { Vref }}
$$

Tegangan referensi (Vref) sebesar 5 volt. Terdapat tiga pengujian pada sensor flex, keadaan jari lurus, keadaan jari menekuk $90^{\circ}$, dan keadaan jari menggenggam sepenuhnya.

1) Keadaan Jari Lurus

Tegangan yang terukur $=3,50$ volt

$$
\text { Data } \mathrm{ADC}=\frac{\operatorname{Vin} \times 1024}{\operatorname{Vref}}=\frac{3,50 \times 1024}{5}
$$

Data $\mathrm{ADC}=716,8$

2) Keadaan Jari Menekuk $90^{\circ}$

Tegangan yang terukur $=3,20$ volt

$$
\begin{gathered}
\text { Data } \mathrm{ADC}=\frac{\operatorname{Vin} \times 1024}{\text { Vref }}=\frac{3,20 \times 1024}{5} \\
\text { Data } \mathrm{ADC}=655,3
\end{gathered}
$$

3) Keadaan Jari Menggengam

Tegangan yang terukur $=3,10$ volt

$$
\text { Data } \mathrm{ADC}=\frac{\operatorname{Vin} \times 1024}{\operatorname{Vref}}=\frac{3,10 \times 1024}{5}
$$

Data $\mathrm{ADC}=634,8$

Hasil persamaan menyatakan bahwa diperoleh perbedaan nilai antara keadaan jari lurus, menekuk $90^{\circ}$ dan menggenggamnya sepenuhnya. Hal tersebut menunjukkan bahwa sensor flex berfungsi dengan baik dan layak digunakan pada penelitian ini.

Pengujian Sensor Grove Finger Clip Heart Rate

Pengujian sensor grove finger clip heart rate dilakukan pembacaan data hasil pada serial monitor, dibandingkan pembacaan detak jantung dengan menggunakan alat omron blood pressure monitor dilihat pada Gambar 5. Hasil pembacaan output sensor grove finger clip heart rate dengan blood pressure monitor diambil secara bersamaan sehingga tertampil hasil perbandingan pembacaan dapat ditunjukkan pada TABEL I.

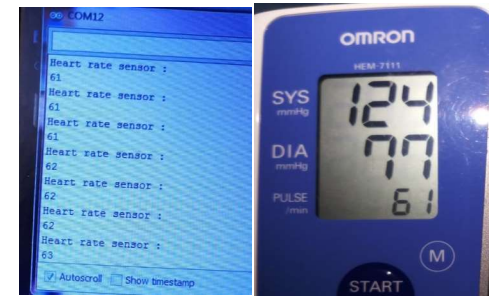

\begin{tabular}{|c|c|c|c|c|c|}
\hline \multirow[b]{2}{*}{ No } & \multirow[b]{2}{*}{ Percobaan } & \multirow{2}{*}{$\begin{array}{c}\text { Max } \\
\text { HR } \\
(b p m)\end{array}$} & \multicolumn{2}{|c|}{$\begin{array}{c}\text { Alat Pendeteksi Heart } \\
\text { Rate }(\mathrm{BpM})\end{array}$} & \multirow{2}{*}{$\begin{array}{c}\text { Error } \\
(\%)\end{array}$} \\
\hline & & & $\begin{array}{c}\text { Grove } \\
\text { Finger } \\
\text { Clip }\end{array}$ & $\begin{array}{c}\text { Blood } \\
\text { Pressure } \\
\text { Monitor }\end{array}$ & \\
\hline 1 & A & 197 & 61 & 61 & 0 \\
\hline 2 & $\mathrm{~B}$ & 197 & 62 & 63 & 1.61 \\
\hline 3 & $\mathrm{C}$ & 197 & 64 & 64 & 0 \\
\hline 4 & $\mathrm{D}$ & 197 & 62 & 63 & 1.61 \\
\hline 5 & $\mathrm{E}$ & 199 & 65 & 66 & 1.53 \\
\hline & \multicolumn{4}{|c|}{ Rata-rata kesalahan (\%) } & 0,95 \\
\hline
\end{tabular}

Gambar 5: Data Deteksi Detak Jantung

TABEL I

Perbandingan Pembacaan Sensor Grove Finger Clip dengan Blood Pressure Monitor.

Diperoleh Tabel 1 nilai perbandingan pembacaan sensor grove finger clip heart rate dengan blood pressure monitor dilakukan sebanyak 5 kali, nilai kedua pembacaan dengan tingkat kesamaan cukup tiinggi. Kemudian didapatkan nilai selisih error sensor grove finger clip heart rate dengan blood pressure monitor sebesar $0.95 \%$. Jadi tingkat keberhasilan sensor grove finger clip heart rate sebagai berikut :

Akurasi Heart Rate $=100 \%-0,95 \%=99,05 \%$

\section{B. Software}

Perangkat keras smart glove dihubungkan dengan aplikasi yang dirancang, microsoft visual basic memulai maka proses inisialisasi awal perangkat, setelah pengkoneksian terhubung, proses berikutnya yaitu proses inisialisasi perubahan nilai adc pada pembacaan sensor flex di setiap jari. Pembacaan data input akan diubah serta diolah pada microsoft visual basic sehingga bisa tertampil data dalam bentuk grafik real time. Hasil pembacaan sensor flex menjadi parameter tingkat kemampuan pasien dalam melakukan terapi. Aplikasi dirancang dengan perangkat lunak microsoft visual basic 2010 dapat ditunjukan pada Gambar 6.

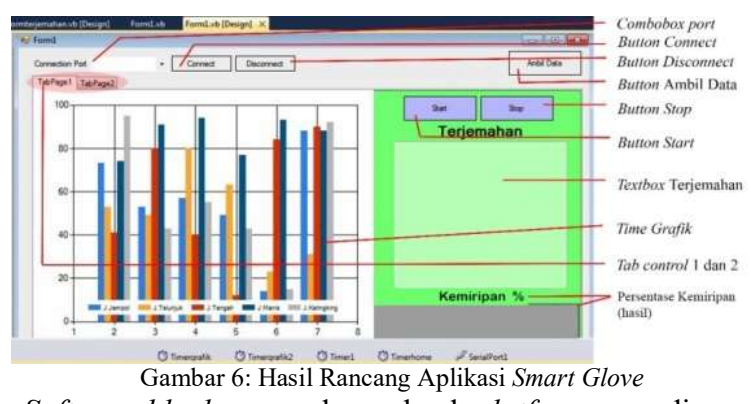

Software blynk merupakan sebuah platform yang digunakan membuat interface untuk mengendalikan dan memonitoring project hardware dari IOS dan perangkat android. Aplikasi 
Majalah Ilmiah Teknologi Elektro, Vol. 20, No.2, Jali-Desember 2021 DOI: https://doi.org/10.24843/MITE.2021.v20i02.P12

yang dirancang untuk menampilkan data sensor grove finger clip heart rate terkoneksi kemudian tahap selanjutnya proses inisialisasi perubahan nilai sensor dalam bentuk BPM (Beat per Menit). Kemudian data yang masuk akan dikonversikan dan diolah mikrokontroler arduino nano dan Esp 8266-01 sehingga dapat menampilkan data keluaran berupa grafik real time. Aplikasi blynk yang dirancang dapat ditunjukan pada Gambar 7.

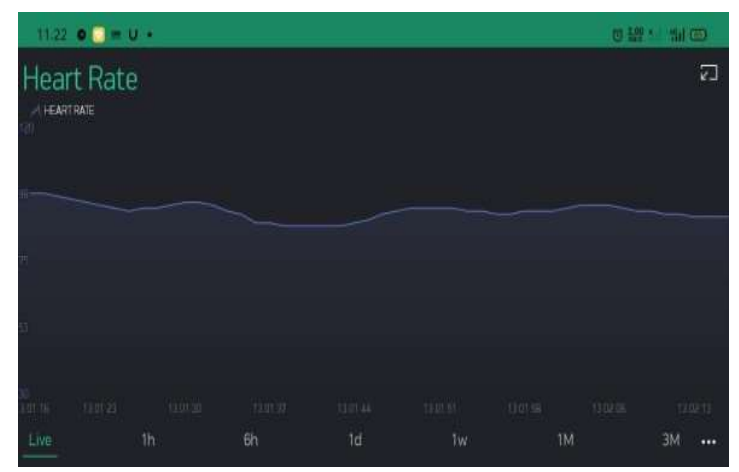

Gambar 7: Hasil Rancang Aplikasi Detak Jantung

\section{HASIL PEMBAHASAN}

Proses pengambilan data dilakukan pada pasien Fisioterapi Murono yang telah dinyatakan pasien pasca stroke mencapai kondisi stabil. Aktifitas terapi jari pasien ter-record oleh sistem dan akan terdapat sebuah nilai parameter apabila nilai gestur jari meningkat maka kondisi pasien semakin membaik. Latihan terapi pasien ditunjukan pada Gambar 8 .

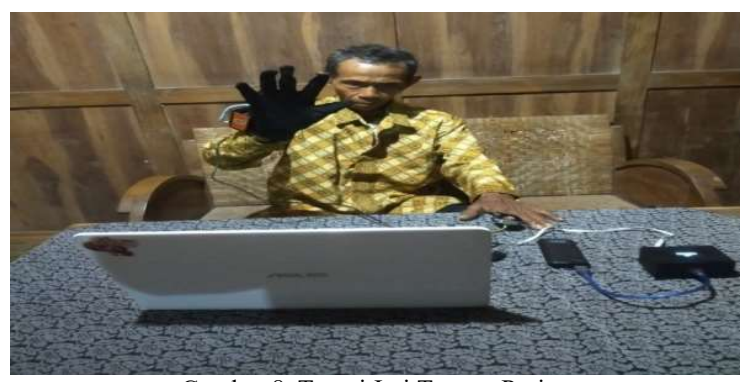

Gambar 8. Tarapi Jari Tangan Pasien

Hasil terapi jari tangan pasien pasca stroke dapat dilihat sebagai berikut.

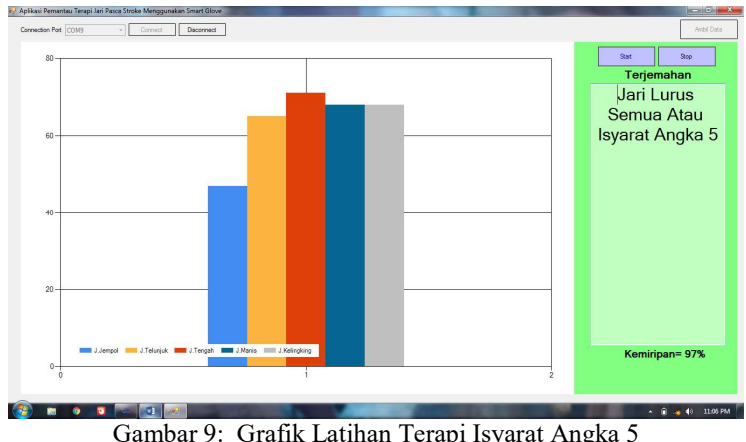

Gambar 9: Grafik Latihan Terapi Isyarat Angka 5

Fajar Setiawan: Implementasi Smart Glove Untuk...

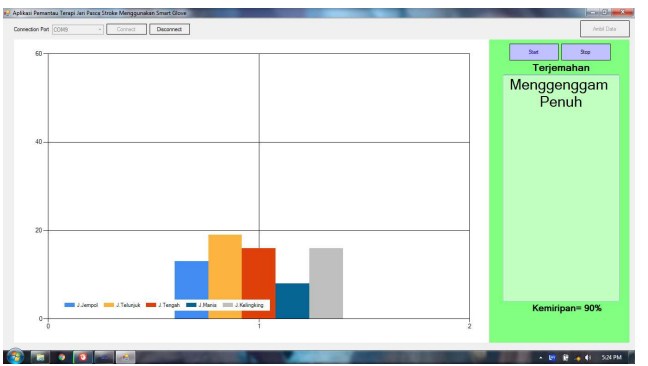

Gambar 10: Grafik Latihan Terapi Menggenggam

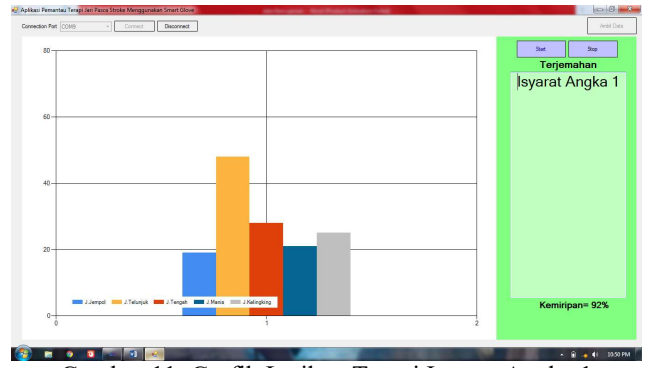

Gambar 11: Grafik Latihan Terapi Isyarat Angka 1

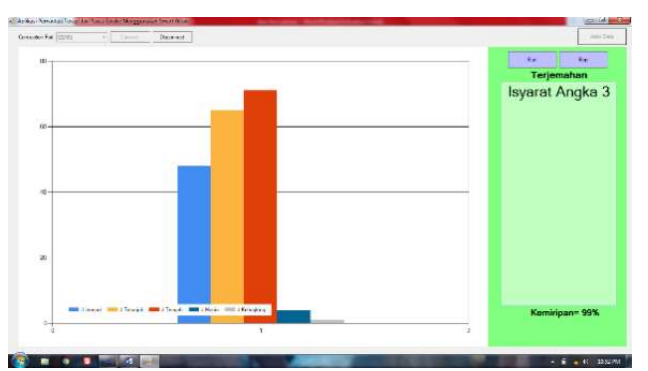

Gambar 12: Grafik Latihan Terapi Isyarat Angka 3

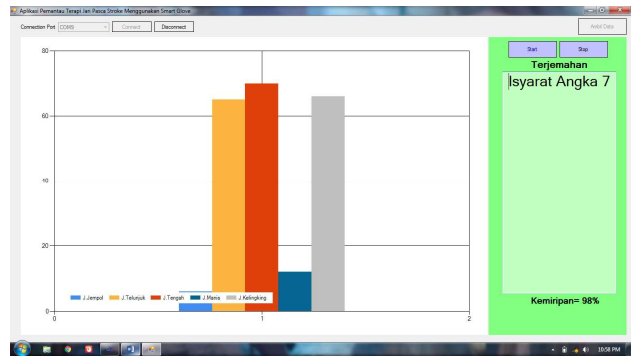

Gambar 13: Grafik Latihan Terapi Isyarat Angka 7

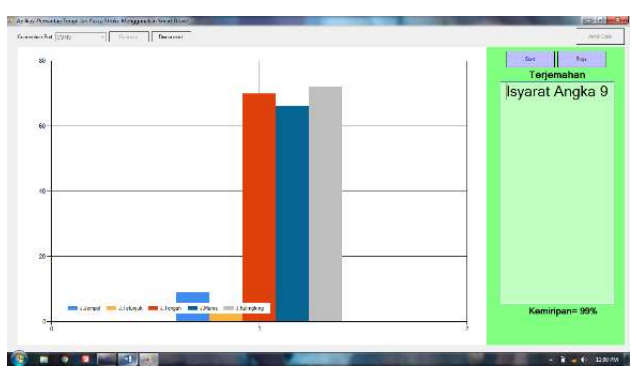

Gambar 14: Grafik Latihan Terapi Isyarat Angka 9 


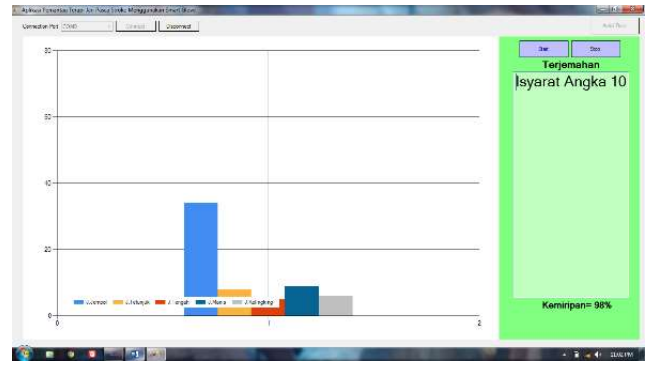

Gambar 15: Grafik Latihan Terapi Isyarat Angka 10

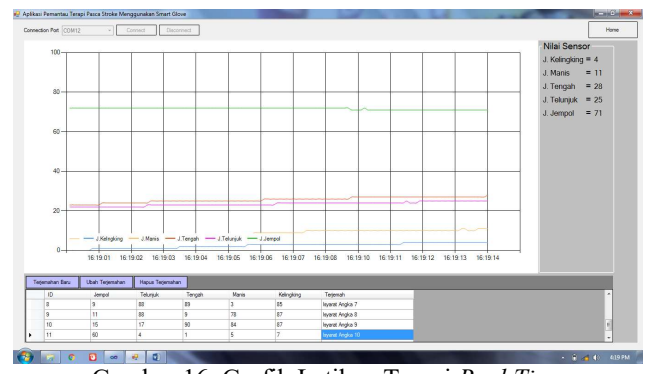

Gambar 16: Grafik Latihan Terapi Real Time

Hasil pendeteksi HR pada pasien pasca stroke dengan nilai batas HR 160 bpm. Data hasil HR akan tersimpan pada aplikasi blynk pada smartphone. Data monitoring heart rate ditunjukan pada Gambar 17. Monitoring HR Pada aplikasi blynk dan monitoring detak jantung pasien pasca stroke pada tanggal 27/03/2021 ditunjukan pada TABEL II.

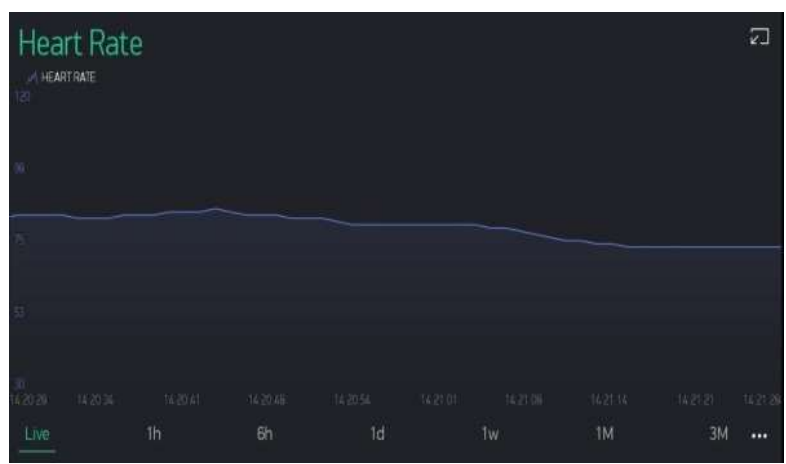

Gambar 17: Data Monitoring Heart Rate Pada Aplikasi Blynk

TABEL II

History Pencatatan HR Tanggal 27/03/2021

\begin{tabular}{|c|c|c|c|}
\hline Tanggal & $\begin{array}{c}\text { Isyarat } \\
\text { Terapi }\end{array}$ & Waktu & $\begin{array}{c}\text { Heart Rate } \\
(\text { bpm })\end{array}$ \\
\hline $27 / 03 / 2021$ & 1 & 14.20 .21 & 82 \\
\hline $27 / 03 / 2021$ & 2 & 14.21 .30 & 81 \\
\hline $27 / 03 / 2021$ & 3 & 14.22 .20 & 82 \\
\hline $27 / 03 / 2021$ & 4 & 14.23 .30 & 82 \\
\hline $27 / 03 / 2021$ & 5 & 14.24 .35 & 82 \\
\hline $27 / 03 / 2021$ & 6 & 14.25 .41 & 83 \\
\hline $27 / 03 / 2021$ & 7 & 14.26 .01 & 82 \\
\hline $27 / 03 / 2021$ & 8 & 14.27 .15 & 83 \\
\hline $27 / 03 / 2021$ & 9 & 14.28 .20 & 84 \\
\hline $27 / 03 / 2021$ & 10 & 14.29 .40 & 83 \\
\hline
\end{tabular}

Sebanyak 10 percobaan, diperoleh data terapi sebesar $90 \%$ keberhasilan ataupun kemiripan. Semakin tinggi nilai keberhasilan ataupun kemiripan yang bisa dicapai, sehingga tingkatan keberhasilan latihan terapi ini akan semakin membaik. Begitu pula dengan deteksi detak jantung pasien pasca stroke dalam kondisi stabil, akan mempercepat pemulihan pasien pasca stroke kembali normal.

\section{KESIMPULAN}

Pengembangan alat bantu rehabilitasi penderita pasca stroke berbasis virtual reality menghasilkan aplikasi terapi latihan gerak aktif setiap jari, gerak terapi jari dilakukan berupa gerakan isyarat angka $1,3,5,7,9,10$ dan keadaan jari menggengam. Latihan gerak aktif setiap jari teruji memberikan peningkatan yang bermakna terhadap daya otot jari pasien pasca stoke. Terapi pasca stroke dilengkapi teknologi grove finger clip heart rate sebagai pendeteksi kondisi detak jantung pada pasien saat melakukan latihan terapi gerak aktif. Pengujian yang dilakukan menunjukkan bahwa didapat data hasil dengan nilai kemiripan diatas $90 \%$. Sedangkan hasil pengujian sensor grove finger clip heart rate didapat tingkat akurasi sebesar $99.05 \%$. Hal tersebut menunjukkan bahwa aplikasi dapat membantu penderita stroke maupun paramedis atau fisioterapis.

\section{UCAPAN TERIMA KASIH}

Penelitian mengucapkan terimakasih kepada seluruh pihak yang telah membantu pengambilan data di tempat Fisioterapi Murono (Jl. Mangkuyudan No.51, Mantrijeron, Kec. Mantrijeron, Kota Yogyakarta, Daerah Istimewa Yogyakarta 55143).

\section{REFERENSI}

[1] K. A. Nugroho and H. Herianto, "Pengembangan Alat Bantu Rehabilitasi Pasien Pascastroke Berbasis Virtual Reality,"J@Ti Undip J. Tek. Ind., vol. 11, no. 1, pp. 45-52, 2016.

[2] J. F. Meschia et al., "AHA / ASA Guideline," Stroke, vol. 45, pp. 3754-3832, 2014.

[3] P. A. Widyaswara Suwaryo, W. T. Widodo, and E. Setianingsih, "Faktor Risiko yang Mempengaruhi Kejadian Stroke," J. Keperawatan, vol. 11, no. 4, pp. 251-260, 2019.

[4] T. J. Kimberley et al., "Study protocol for a pivotal randomised study assessing vagus nerve stimulation during rehabilitation for improved upper limb motor function after stroke," Eur. Stroke J., vol. 4, no. 4, pp. 363-377, 2019.

E. J. Benjamin et al., Heart Disease and Stroke Statistics-2019 Update: A Report From the American Heart Association, vol. 139, no. 10. 2019.

M. Rahmadiva, A. Arifin, M. H. Fatoni, and S. H. Baki, "Rancang Bangun Hand Tracking Glove sebagai Antarmuka untuk Game Rehabilitasi," J. Tek. ITS, vol. 9, no. 1, pp. A36-A41, 2020.

] A. W. Setiawan, L. N. Rizalputri, and A. H. Thias, "Pengembangan alat bantu komunikasi penderita Pascastroke Development of Communication Assistive Device Using Flex Sensor and Accelerometer for Post-Stroke Patient," J. Teknol. Inf. dan Ilmu Komput., vol. 6, no. 2, pp. 129-134, 2018.

F. Teknik and F. Kedokteran, "Sistem monitoring detak jantung dan lokasi pasien," vol. 15, no. 1, pp. 124-133, 2018.

J. Ilmiah and K. Keperawatan, "Aplikasi Mhealth Dalam Deteksi, Monitoring Dan Perubahan Gaya Hidup Pasien Penyakit Jantung," vol. 15, no. 2, pp. 1-7, 2019.

M. Maalej, A. Mtibaa, and F. Gargouri, "Ontology-based User Model for Personalized Search in a Social Network Ontology-based User Model for Personalized Search in a Social Network," no. February 2020, pp. 87-106, 2018. 
Majalah Ilmiah Teknologi Elektro, Vol. 20, No.2, Jali-Desember 2021

DOI: https://doi.org/10.24843/MITE.2021.v20i02.P12

[11] G. Hassan, A. M. Rashwan, and H. S. Hassanein, "SandBoxer: A Self-Contained Sensor Architecture for Sandboxing the Industrial Internet of Things," no. May, 2019.

[12] S. Zulhuda, "The concept of internet of things and its challenges to privacy," vol. 8, no. 4, pp. 1-6, 2015.

[13] I. K. R. Arthana and I. M. A. Pradnyana, "Perancangan alat pendeteksi detak jantung dan notifikasi melalui sms 1,2," Semin. Nas. Ris. Inov., pp. 889-895, 2017.

[14] M. Suari, "Pemanfatan Arduino nano dalam Perancangan Media," Nat. Sci. J., vol. 3, no. 1, pp. 474-480, 2017.

[15] S. A. Akbar, Sunardi, Harianto, and F. Noviyanto, "Irrigation Distribution System for Agriculture using Fuzzy Control and Android-Based Water Monitoring," vol. 189, pp. 45-49, 2019.

[16] D. K. Ilmiah et al., "Rancang Bangun Sistem Komunikasi Data Game Controller Menggunakan Bluetooth Pada Robot Humanoid Soccer," H. Wibisono, Y. Purwanto dan W. A. Prasetyanto, pp. 5-6, 2015.

[17] A. Zainuri, U. Wibawa, and E. Maulana, "Implementasi Bluetooth HC - 05 untuk Memperbarui Informasi Pada Perangkat Running Text Berbasis Android," Eeccis, vol. 9, no. 2, pp. 164-165, 2015.

[18] M. Arifin, U. Nadiya, A. Ivonita Simbolon, N. Agung Mahardiono, and I. Purnama, "Karakterisasi Respon Sensor Flex pada Pergerakan Jari Berdasarkan Sudut kemiringan," J. Otomasi Kontrol dan Instrumentasi, vol. 11, no. 1, p. 15, 2019.

[19] S. Muharom and T. Tukadi, "Wheelchair Robot Movements Using Flex Sensor Glove," J. Inf., vol. 3, no. 2, p. 84, 2018.

[20] Musayyanah1, I. Puspasari, and P. Susanto, "Monitoring Target Heart Rate ( Thr ) Untuk Optimalisasi," Tek. Eng. Sains Journal. Inst. Bisnis dan Inform. Stikom Surabaya, vol. 2, no. 2, pp. 87-94, 2018 .

[21] K. Karnadi, "Pengembangan Aplikasi Digital Image Processing Dengan Microsoft Visual Basic," J. Digit. Teknol. Inf., vol. 1, no. 1, p. 15, 2018.

[22] Y. Yusnita, "Aplikasi Microsoft Visual Basic 6.0 Dalam Pembuatan Kartu Hasil Studi Mahasiswa Jurusan Matematika Universitas Andalas," PYTHAGORAS J. Progr. Stud. Pendidik. Mat., vol. 8, no. 1, pp. 11-22, 2019

[23] H. Shull, "SISTEM PENGAMANAN PINTU RUMAH BERBASIS Internet Of Things (IoT) Dengan ESP8266," Science (80-. )., vol. 195 , no. 4279, p. 639, 1977, [Online]. Available: https://ojs.uniskabjm.ac.id/index.php/JIT/article/view/661.

[24] D. Kurniawan and A. Witanti, "Prototype of Control and Monitor System with Fuzzy Logic Method for Smart Greenhouse," Indones. J. Inf. Syst., vol. 3, no. 2, p. 116, 2021.

Fajar Setiawan: Implementasi Smart Glove Untuk...

p-ISSN:1693 - 2951; e-ISSN: 2503-2372 
\{ Halaman ini sengaja dikosongkan \} 